OPEN ACCESS

Vol. 9, No. 1, April, 2021

Page. $11-21$

DOI: https://doi.org/10.21107/jaffa.v9i1.1032
JOURNAL OF AUDITING, FINANCE, AND FORENSIC ACCOUNTING

E-ISSN: 2461-0607 ISSN: 2339-2886

https://journal.trunojoyo.ac.id/jaffa

\title{
The Determinant of Internet Financial Reporting: Evidence From Asean Stock Exchange
}

Angela, Dyna Rachmawati*

Accounting Departement, Faculty of Economics and Business, Widya Mandala Catholic Surabaya University

\section{Article Info:}

Received: April 6, 2021

in revised form: April 14, 2021

Accepted: 22 April 2021

Available Online: 30 April 2021

\section{Keywords:}

IFR, Profitability, Liquidity, Leverage, Market activity

\section{Corresponding Author:}

Email: dyna@ukwms.ac.id

\begin{abstract}
This research aims to analyze the effect of profitability, liquidity, leverage, and market activity on Internet Financial Reporting (IFR). This research was conducted at consumer goods sub-sector manufacturing companies listed on the ASEAN Stock Exchange in 20182019. This research used the purposive sampling method. The samples consisted of 378 companies. The data analysis technique used in this research is multiple linear regression analysis techniques. Based on the results of the analysis, it can be seen that the profitability variable has a positive effect on IFR, while the liquidity variable has a negative effect on IFR, then leverage and market activity have no effect on internet financial reporting, where greater leverage and market activity do not make the present company information on internet financial reporting.
\end{abstract}

Abstrak; Penelitian ini bertujuan untuk menganalisis pengaruh profitabilitas, likuiditas, leverage, dan market activity terhadap pengungkapan Internet Financial Reporting (IFR). Penelitian ini dilakukan pada perusahaan manufaktur subsektor consumer goods yang terdaftar di Bursa Efek ASEAN pada tahun 20182019. Penelitian ini menggunakan metode purposive sampling. Sampel terdiri dari 378 perusahaan. Teknik analisis data yang digunakan dalam penelitian ini adalah teknik analisis regresi linier berganda. Berdasarkan hasil analisis, dapat disimpulkan variabel profitabilitas berpengaruh positif terhadap IFR, sedangkan variabel Likuiditas berpengaruh negatif terhadap IFR, kemudian untuk leverage dan market activity tidak berpengaruh terhadap internet financial reporting, dimana semakin besar leverage dan market activity tidak membuat perusahaan menyajikan informasi di internet financial reporting. 


\section{INTRODUCTION}

The evolution of internet technology and the development of global markets create new opportunities for business activities. The internet is becoming easy to use for corporate disclosure. Through the internet, the information obtained is of higher quality and quantity, cheaper costs and without wider barriers to reach users across regions and even countries. The high number of internet users has encouraged companies to be able to attract more investors in various geographic areas (Hussain, Rehman, and Ishaq, 2018). Companies in various countries see this phenomenon as an opportunity to consider the internet as an opportunity to disseminate information with company websites (Reskino and Sinaga, 2016). The internet is the tool used to deliver and communicate corporate information to external parties. The use of the internet to communicate information by the company's website is called Internet Financial Reporting (IFR). IFR is the form of disclosure of the company's financial statements through the internet or the company's website and as a form of voluntary disclosure.

Agency theory is the basis for the implementation of IFR; agency theory defines that there is a relationship between the principal, namely the investor and the agent, namely management. With the existence of IFR, disclosure can be done more broadly; this will increase the trust between investors and management so as to minimize agency conflicts. Agency conflicts will arise when management has better and more information than investors, this is what triggers information asymmetry (Jensen and Meckling, 1976). This information asymmetry can lead to agency costs; these costs arise because investors want to ensure that management has not taken any adverse actions and has taken full action to maximize investor welfare.

IFR in each company has differences in terms of what is conveyed; these differences cause the benefits obtained from its application to each company and investors are different. The more and easier the information obtained, the easier it will be to make decisions for the benefit of investors. Then with a high level of information disclosure will have an impact and influence on investors' decisions in the future (Pervan, 2006). Therefore, it is necessary to know the determinants that encourage companies to implement IFR. This study uses four determinants as independent variables. There are profitability, liquidity, leverage, and market activity. The main reason for choosing the four determinants is because they are used in the fundamental analysis. The company's fundamental analysis has purposed. First, it can be seen the weaknesses and strengths of the company. Second, it identifies the movement of the company's growth. And finally, the determinants can be compared which companies have the most prospects and are the most profitable (Manurung and Haryanto, 2015). Then, the purpose of this study is to examine which determinant that most influences IFR disclosure.

Profitability is the first determinant that affects IFR. The profitability ratio is useful to show the success of the company in generating profits. Companies with good profitability tend to disclose complete financial information. Yassin (2017) states that profitability has a positive effect on IFR for companies located in Jordan. Ardiastuti, et al. (2019) shows that profitability has a negative effect on IFR in manufacturing companies in Indonesia. The second determinant is liquidity that can affect IFR. The liquidity ratio has an effect on showing a company's ability to meet its short-term liabilities in a liquid (current) manner. This condition encourages company managers to disseminate this information. One way is through IFR. Handoko and Fuad (2013), in their research, shows that the results of liquidity have a positive effect on IFR in companies listed on the Indonesia Stock Exchange (BEI) in 2011. According to Omran and Ramdhony (2016), liquidity has a negative effect on IFR for companies listed on the Mauritius Stock Exchange (SEM), East Africa. The third determinants that affect IFR are leverage. The leverage ratio is often used by investors to see and measure the company's ability to pay off its current obligations. Andriyani and Mudjiyanti (2017) show that the leverage ratio has a positive effect on IFR in manufacturing companies in Indonesia. In contrast to this research, research conducted by (Reksino and Sinaga, 2016) on the property and real estate companies in Indonesia shows leverage has no effect on IFR. The fourth determinant is a market activity that shows the activity of stock price movements in the market because, with high market activity, the value of shares owned by the company will be increasingly expensive and high (Budianto, 2018). In Indonesia, 
research conducted by Budianto (2018) states that market activity has a positive effect on IFR in manufacturing companies in Indonesia. Yassin (2017), in his research in Jordan on all, go public companies in 2011 , revealed that market activity had no effect on IFR. Previous studies reveal that there are inconsistencies in whether profitability, liquidity, leverage, and market activity have an impact on IFR. It motivates this study to test the determinants of IFR in the ASEAN market.

The result shows that profitability has a positive impact on IFR. It indicates that profitability is the determinant that has the most influences to encourage the companies to disclose information on IFR. Profitability is a determinant that can reduce information asymmetry as an agency problem. The result also shows that liquidity has a negative impact on IFR. It indicates that liquidity is a determinant that can cause agency problem in the form of information asymmetry. The companies tend to hold the information when there is a shortage of liquidity and otherwise. At the same time, leverage and market activity has no impact on IFR. It reveals that those are not the determinant of IFR.

This study also makes the additional test. The purpose of the additional test is to examine whether profitability, liquidity, leverage, and market activity are the determinants of IFR in each market of ASEAN countries. The countries are Indonesia, Malaysia, Singapore, the Philippines, and Thailand. There is a goodness of fit problem when we regress profitability, liquidity, leverage, and market activity on IFR. This is why we add firm size as an independent variable into the regression model. The additional test shows that first, profitability has a positive impact on IFR in Singapore and Thailand stock exchange. Second, liquidity has a negative impact on IFR in the Thailand stock exchange. But, there is no evidence in the other countries stock exchange. Third, there is mix result on leverage as an IFR determinant. Leverage has a positive impact on IFR in the Thailand stock exchange. But, leverage has a negative impact on IFR in Indonesia and Malaysia stock exchange. Forth, market activity has no impact on IFR in all of the countries. And finally, firm size has a positive impact on IFR in Indonesia, Malaysia, Philippines and Thailand stock exchange. The additional test concludes that firm size is the determinant that most influences on IFR in almost ASEAN countries except Singapore.

\section{LITERATURE REVIEW AND HYPOTHESES DEVELOPMENT}

\section{Agency Theory}

Agency theory, according to Jensen and Meckling (1976) is an agency relationship that arises when a group or person (principal) employs another party (agent) to receive authority or mandate in decision making. The principal is the owner of the capital or the shareholder, while the agent is the manager of the company. According to Kurniawati (2018) the main principle of agency theory is the theory that underlies the relationship between principals and agents in a cooperation contract. According to Zamroni (2018) there are three types of agency relationships, namely the relationship between managers and owners or investors, the relationship between managers and creditors, and the relationship between managers and the government.

The principal gives authority to management, and management is responsible for the authority received by trying to achieve the goals of each party in accordance with the cooperation contract. The desired goal of the principal is to get the maximum benefit from company performance, while the management tries to work efficiently to get a reward (Linda and Khikmawati, 2015; in Andriyani and Mudjiyanti, 2017). According to Debrecency (2002, in Rizki and Ikhsan, 2018), agency teori illustrates that the cooperative relationship between the two parties has different interests and will cause problems, namely, agency costs and information asymmetry. Information asymmetry occurs due to an imbalance of information provided by management to the principals in carrying out the company's operational activities. Information asymmetry can lead to agency costs, and these costs are incurred in an effort to supervise and evaluate management performance carried out by independent auditors (Abdillah, 2015).

Jensen and Meckling (1976) reveal that agency theory seeks to avoid problems arising from differences of interest by sharing accounting information in a transparent and relevant manner so that all interested parties can obtain the same information. In an effort to overcome the problem of information asymmetry, information disclosure 
through voluntary disclosure can be a means of reducing agency costs (Abdillah, 2015). IFR is a voluntary disclosure tool that can be a solution to reduce information asymmetry and agency costs. IFR is expected to be a medium for management to report overall company information to all stakeholders by prioritizing information transparency and can reduce problems that occur both in terms of information asymmetry and agency costs (Kurniawati, 2018). Therefore, the presence of IFR is expected to be used by companies in an effort to reduce problems that arise both in terms of information asymmetry and agency costs.

This study uses agency theory to explain the determinants that affect the company in disclosing its financial information through IFR. The determinants are factors that can reduce agency problems by minimizing information asymmetry. There are profitability, liquidity, leverage, and market activity.

\section{The Profitability on Internet Financial Reporting (IFR)}

Profitability is an indicator of good management of a company related to earning profits in relation to total asset sales and its own capital (Almilia, 2008). Profitability is an important aspect that investors pay attention to as a reference for assessing management performance in managing the company. Profitability is said to be good if the company can make a good rate of return on investment and credit. Companies with high profitability will have a strong incentive to disseminate company information, especially financial information (Budianto, 2018).

Companies with increased profitability will be able to attract investors' attention, and when this happens, management will disclose more of this information to the public (Almilia, 2008). In addition, companies that have good financial performance will make this an opportunity to increase public confidence, especially investors in companies (Ilmawati and Indrasari, 2018). In contrast, companies that have low profitability will try to cover up this information (Omran and Ramdhony, 2016). Therefore, the level of profitability will affect IFR. So based on the description above it can be concluded the following hypothesis:

\section{H1: Profitability has a positive impact on Internet Financial Reporting (IFR)}

\section{The Liquidity on Internet Financial Reporting (IFR)}

Liquidity shows the company's ability to pay its short-term obligations (Ilmawati and Indrasari, 2018). A company can be said to have a good level of liquidity if it is able to meet its short-term obligations when they are collected (Zamroni, 2018). It can be said that a high level of liquidity shows that the company has the ability to pay off short-term debt faster than its competitors (Reskino and Sinaga, 2016). Investors will be more interested in companies with high liquidity, and this will encourage management to try to more broadly disclose this information to the public (Omran and Ramdhony, 2016).

Investors who are interested in high liquidity values encourage management to disclose it in financial reporting, one of which is through IFR (Ilmawati and Indrasari, 2018). Companies that have high liquidity numbers will make this an opportunity to increase public confidence, especially investors, in company performance and try to reveal it more broadly with IFR (Omran and Ramdhony, 2016; Reskino and Sinaga, 2016). Therefore, a high level of liquidity will affect IFR. According to the description above, the following hypothesis can be concluded:

\section{H2: Liquidity has positive impact on Internet Financial Reporting (IFR)}

\section{The Leverage on Internet Financial Reporting (IFR)}

Leverage is a tool used to measure a company's ability to pay off its debts when due (Kieso et al., 2018: 5-4). According to (Putri and Azizah, 2019) leverage can be interpreted as a measure of the number of assets that are financed using liabilities. Fraser and Ormiston (2004: 177) reveal that the leverage ratio measures the extent to which spending is made with debt compared to capital and the ability to pay interest and other fixed expenses. The leverage ratio shows how much the company's operations are financed by debt; a high leverage rate will affect investors' assessment of the company's performance (Malawat, 2016). 
Leverage is a tool used to measure a company's ability to pay off its debts when due (Kieso et al., 2018: 5-4). The leverage ratio shows how much the company's operations are financed by debt; a high leverage rate will affect investors' assessment of the company's performance (Malawat, 2016). Companies that have high leverage can incur agency costs (Omran and Ramdhony, 2016). This shows that a company that has a high leverage value has an obligation to meet information needs regarding the company's ability to pay its obligations. According to (Andriyani and Mudjiyanti, 2017), the existence of interests related to creditors and investors regarding the condition of the company and to reduce the incidence of agency costs makes management try to disclose more through IFR. Therefore, the level of leverage will affect IFR. Based on the description above, the third hypothesis is obtained:

H3: Leverage has impact positive on Internet Financial Reporting (IFR)

\section{The Market Activity on Internet Financial Reporting (IFR)}

Market activity is an activity carried out by companies related to securities trading and offering securities to the public with the aim of increasing company capital to expand business (Tandelilin, 2010). Market activity can also be an assessment of how much active stocks are in the market and indicates an increase in share value. If the company's shares are in high demand on the trading market, this can motivate managers to report and improve the quality of IFR, which is broader and more transparent to the public, especially investors (Indahsari, 2019).

Market activity is an activity carried out by companies related to securities trading and offering securities to the public with the aim of increasing the company's capital in order to expand its business (Tandelilin, 2010). If the company's shares are in high demand on the trading market, this can motivate managers to report and improve the quality of IFR, which is broader and more transparent to the public, especially investors (Indahsari, 2019). Pervan (2006), in his research, states that investors will be motivated to seek broader information related to companies whose shares are actively traded. Pervan (2006) also stated that the high market activity of a company would make the stock price increase in value or become more expensive. Based on the explanation above, the hypothesis to be tested can be described as follows:

H4: Market Activity has a positive impact on Internet Financial Reporting (IFR)

\section{RESEARCH METHODOLOGY}

\section{Research Model}

The research model is used to test the hypotheses as bellows:

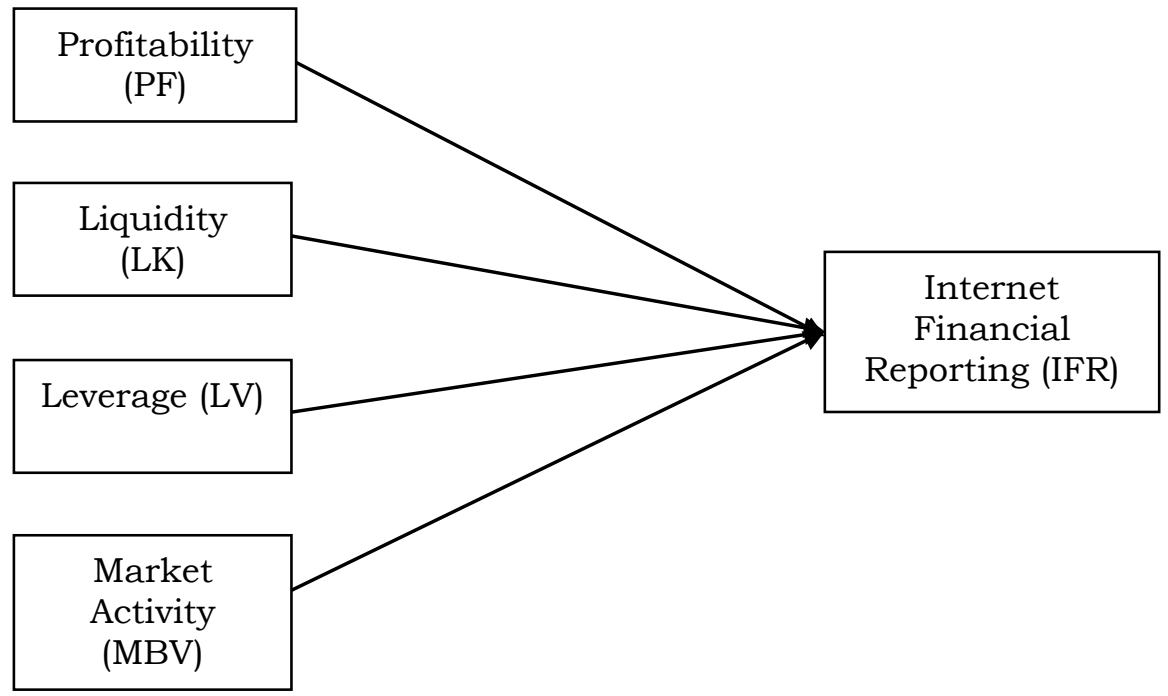

Figure 1

Research Model 
The research model above is translated into research equation no (1) as follows:

$I F R_{i}=\beta_{0}+\beta_{1}{ }^{*} P F_{i}+\beta_{2}{ }^{*} L K_{i}+\beta_{3}{ }^{*} L V_{i}+\beta_{4}{ }^{*} M B V_{i}+\varepsilon_{i}$ ..(1)

Equation no (1) is the main test of hypotheses. Hypotheses $1-4$ are proven empirically if $\beta_{1}-\beta_{2}$ are significant and positive.

\section{Operationalization and Measurement of Variable}

Table 1

Operational and Measurement of Variables

\begin{tabular}{|c|c|c|c|c|}
\hline \multicolumn{2}{|c|}{ Variable } & Operational & Measurement & Reference \\
\hline \multirow[t]{4}{*}{ Dependent } & $\begin{array}{l}\text { Internet } \\
\text { Financial }\end{array}$ & $\begin{array}{l}\text { IFR is a method of } \\
\text { reporting by }\end{array}$ & Index of IFR = & Yassin (2017) \\
\hline & Reporting (IFR) & companies to & $\sum$ item disclosed $\times 100 \%$ & \\
\hline & & present their & 30 item & \\
\hline & & $\begin{array}{l}\text { financial reports via } \\
\text { the internet and } \\
\text { company websites }\end{array}$ & $\begin{array}{l}30 \text { item of IFR } \\
\text { disclosures are in } \\
\text { Apendix A }\end{array}$ & \\
\hline \multirow[t]{10}{*}{ Independent } & Profitability (PF) & $\begin{array}{l}\text { Profitability is the } \\
\text { financial }\end{array}$ & $\mathrm{ROE}=$ & $\begin{array}{l}\text { Subramanyam } \\
\text { (2010:9); }\end{array}$ \\
\hline & & achievement of the & net income $\times 100 \%$ & Kieso et al. \\
\hline & & $\begin{array}{l}\text { companies from } \\
\text { their operational } \\
\text { activities. }\end{array}$ & equity & \\
\hline & Liquidity (LK) & $\begin{array}{l}\text { Liquidity is the } \\
\text { ability of the }\end{array}$ & Current ratio $(\mathrm{CR})=$ & $\begin{array}{l}\text { Kieso et al. } \\
(2018: 5-4)\end{array}$ \\
\hline & & $\begin{array}{l}\text { companies to pay } \\
\text { the current } \\
\text { liabilities }\end{array}$ & $\begin{array}{l}\text { current assets } \times 100 \% \\
\text { current liabilities }\end{array}$ & \\
\hline & Leverage (LV) & $\begin{array}{l}\text { Leverage is the } \\
\text { company's ability to } \\
\text { pay off its }\end{array}$ & $\begin{array}{l}\text { Debt to equity ratio } \\
(\mathrm{DER})=\end{array}$ & $\begin{array}{l}\text { Kieso et.al. } \\
(2018: 5-4) \\
\text { Frasser and }\end{array}$ \\
\hline & & $\begin{array}{l}\text { obligations when } \\
\text { they are due. }\end{array}$ & $\frac{\text { Debt }}{\text { Equity }} \times 100 \%$ & Ormiston \\
\hline & $\begin{array}{l}\text { Market activity } \\
\text { (MBV) }\end{array}$ & $\begin{array}{l}\text { Market activity is an } \\
\text { activity of buying } \\
\text { and selling company }\end{array}$ & $\begin{array}{l}\text { Market to book value } \\
(\mathrm{MBV})=\end{array}$ & $\begin{array}{l}\text { Budianto } \\
\text { (2018); Yassin } \\
\text { (2017) }\end{array}$ \\
\hline & & long-term financial & A market value $\times 100 \%$ & \\
\hline & & $\begin{array}{l}\text { instruments to the } \\
\text { public with the aim } \\
\text { of increasing the } \\
\text { company's capital in } \\
\text { order to expand its } \\
\text { business. }\end{array}$ & Equity value & \\
\hline
\end{tabular}

Source: Processed Data

\section{Research Overview}

The population of this study is the consumer goods industry listed in ASEAN stock exchange during periods 2018-2019. The total populations are 644 firm years. The sampling technique is purposive. Table 2 shows the sample criteria.

\section{Table 2}

\section{Sample Criteria}

\begin{tabular}{llr}
\hline No & \multicolumn{1}{c}{ The Sample Criteria } & Total \\
\hline 1. & $\begin{array}{l}\text { The consumer goods companies that are listed in ASEAN } \\
\text { market periods 2018-2019 }\end{array}$ & 644 \\
\hline 2. & $\begin{array}{l}\text { The consumer goods companies in ASEAN market that do not } \\
\text { make available during periods 2018-2019 }\end{array}$ & (40) \\
\hline 3. & $\begin{array}{l}\text { The websites of consumer goods companies that can not be } \\
\text { accessed during collecting data }\end{array}$ & $\begin{array}{l}\text { (34) } \\
\text { The consumer goods companies do not have complete report } \\
\text { periods 2018-2019 }\end{array}$ \\
\hline 5. & The consumer goods companies do not have annual report in \\
\hline
\end{tabular}




\begin{tabular}{lll}
\hline & English & $(20)$ \\
\hline 6. & Total companies that fulfil the sample criteria & 456 \\
\hline 7. & Outlier & $(78)$ \\
\hline 8. & Total companies used as sample & 378 \\
\hline \multicolumn{2}{l}{ Source: Processed Data }
\end{tabular}

Table 2 shows that the sample used in this study is 378 firm-year.

FINDINGS AND DISCUSSION

\section{Descriptive Statistic}

The determinants of IFR are profitability (PF), liquidity (LK), leverage (LV), and market activity (MBV). The statistic descriptive is shown in Table 3 below:

Table 3

Descriptive Statistic

\begin{tabular}{lrrrr}
\hline Variable & Min & Max & Mean & $\begin{array}{c}\text { Std. } \\
\text { Devices }\end{array}$ \\
\hline IFR & 0.233 & 0.967 & 0.674 & 0.132 \\
\hline PF & -0.930 & 0.415 & 0.070 & 0.130 \\
\hline LK & 0.234 & 9.330 & 2.599 & 1.905 \\
\hline LV & 0.065 & 4.061 & 0.792 & 0.707 \\
\hline MBV & 0.138 & 9.318 & 1.797 & 1.738 \\
\hline Source: processed data & & &
\end{tabular}

Table 3 shows that the minimum value of IFR is $23 \%$ owned by company in Indonesia. The maximum value of IFR is $96.7 \%$ owned by company in Thailand. the mean value of IFR IS $67.4 \%$, and the standard deviation is 0.1324 , WHich indicates that the variation between sample companies is low.

Table 3 also shows the descriptive of the determinants. The minimum and maximum value of profitability (PF) is $-93 \%$ owned by companies in Malaysia and $41.5 \%$ owned by companies in Singapore. The mean value and standard deviation of $\mathrm{PF}$ is $7 \%$ and 0.130. It indicates that PF of the sample companies is low. The liquidity (LK) proxy by current ratio has minimum value of 0.234 for philippines's company. the maximum value is 9.331; it also owned by companies in the Philippines. The mean value of LK is 2.599 , and the standard deviation is 1.905. It indicates the sample companies have current assets twice above their current liability. This means that the sample companies are able to pay their short-term liabilities on average because the company's current assets are 2.599 greater than their short-term liabilities. The minimum (maximum) value of leverage (LV) is 0.065 (4.061) owned by companies in Malaysia (Thailand). The mean value (standard deviation) of LV is 0.797 (0.707). It indicates that the financing of the sample companies come from equity. The minimum (maximum) value of market activity proxy by market to book value (MBV) is 0.138 for Malaysian's company $(9.318$ for Thailand's company). The mean value (standard deviation) is 1.797 . it indicates the market value of the sample companies is $80 \%$ higher than book value.

\section{Results}

Hypotheses testing in this study use multiple regression analysis. We use several steps before test hypotheses. The first step is conducting normality test. We use Kolmogorov-Smirnov test to identify whether the residual distribution based on equation (1) is normal. The result shows that the significance of unstandardized residual is 0.392 . The value is above $p$-value 0.05 . It means that the residual distribution is normal. The second step is heteroscedasticity test. We use Glejser test. The result shows that the sign is 0.098 above p-value 0.05 . it means that there is no heteroscedasticity. the third step is multicolineartity test. the results show that tol values are above 0.10 and vif are below 10. it means that there are no correlations within independent variables. we do not test autocorelations as the data used in this study are cross section. So we could ignore the time dimensions to be tested in autocorelations.

The last step, before testing hypotheses, is goodness of fit. We use $\mathrm{R}^{2}$ and F-test. $\mathrm{R}^{2}$ is $7.5 \%$. The score indicates that the ability of independent variables to explain IFR is 
$7.5 \%$. F-Test IS 7.707 , ot the significance value is 0.000 below $p$-value 0.05 . It means that the research model can be used to test hypotheses. The result of regression analysis is shown in Table 4 below:

\begin{tabular}{lrrl}
\multicolumn{4}{c}{ Table 4} \\
Hypotheses Testing \\
\hline Variable & Beta & t-value & Sig \\
\hline Constanta & 0.683 & 35,195 & 0,000 \\
\hline PF & 0.214 & 3,868 & $0,000^{* * *}$ \\
\hline LK & -0.011 & $-2,702$ & $0,007^{* * *}$ \\
\hline LV & -0.005 & $-0,460$ & 0,646 \\
\hline MBV & 0.005 & 1,278 & 0,202 \\
\hline$* * *$ Sign at p-value $1 \%$ & & \\
Source: processed data & &
\end{tabular}

Table 4 above shows that PF is significant and positive on IFR. It means $\mathrm{H} 1$ is supported. Profitability (PF) proxy by ROE is the determinant of IFR. profitability is determinant to reduce information asymmetry. it indicates that the agency problem will below for companies with higher profitability because they tend to disclose information by IFR. Liquidity (LK) is significant and negative. Current ratio is the measurement of liquidity (LK). companies with high liquidity tend to hold IFR disclosure and otherwise. It means $\mathrm{H} 2$ is not supported. Liquidity is the determinant of IFR. But, it has the role to raise agency problem by hold information disclosure using IFR for the companies with high liquidity rather than low liquidity.

Table 4 also shows that LV and MBV is not significant on IFR. LV (MBV) represents leverage (market activity). it means that $\mathrm{H} 3$ and $\mathrm{H} 4$ is not supported. leverage and market activity are not the determinants of IFR.

\section{The Impact of Profitability on Internet Financial Reporting}

Profitability has positive impact on IFR. The companies with high profitability tend to disclose information in IFR rather that companies with low profitability. it means that the information asymmetric in companies with high profitability is low. As they tend to disclose information on IFR. It indicates that the agency problem in those companies is lower than the other companies with low profitability. The companies with low profitability tend to hold the disclosure on IFR. This could raise information asymmetry.

Profitability is the determinant of IFR. Table 4 shows that regression coefficient or beta value is the highest among the other determinant 0.214 . It represent the sensitivity of profitability on IFR is the high. If the profitability of companies has changed, the IFR will be affected immediately. This study concludes that profitability is the determinant that most influenced IFR.

the result of profitability on IFR in this study has supported previous studies. andriyani and mudjiyanti (2017), Yassin (2017), Budianto (2018), Ilmawati and Indrasari (2018) have shown that profitability has positive impact on IFR. Differ from those results, Omran dan Ramdhony (2016) show that profitability has no impact on IFR.

\section{The Impact of Liquidity on Internet Financial Reporting}

Liquidity has negative impact on IFR. The companies with high (low) liquidity tend to disclose less (more) information in IFR. The information of liquidity is easy to be understood by external users. For companies with high liquidity, this information is considered enough by the companies so that they disclose less on IFR. This can raise agency problem as the information asymmetric tend to be high. the opposite for the companies with low liquidity, they tend to disclose information on ifr more. the effort is to make the report "beauty" as the liquidity is low. Liquidity is the determinant of IFR, but the sensitivity of liquidity is low. Table 4 shows the beta score is -0.011. It means that liquidity is not the most influenced of IFR.

this result supports omran and ramdhony (2016) that proved the liquidity has negative impact on IFR. but it does not support Handoko and Fuad (2013). Handoko and Fuad find that liquidity has positive impact on IFR. 


\section{The Impact of Leverage on Internet Financial Reporting}

The results of this study do not support the third hypothesis. Leverage is not significant to IFR. This means that leverage is not a determinant that affects companies in disclosing information on IFR. Management in conducting financial reporting through the company's website is not determined by leverage. It is hoped that the openness carried out by management through IFR will increase the confidence of investors and creditors (Reskino and Sinaga, 2016).

The results obtained show that the results of leverage have no effect on IFR and are in line with Yassin's research, 2017; Hussain, Rehman, and Ishaq, 2018; Ilmawati and Indrasari, 2018 which showed that the results of leverage had no effect on IFR. however, the results of this study contradict the research of andriyani and mudjiyanti, 2017, which states that profitability has no effect on IFR.

\section{The Impact of Market Activity on Internet Financial reporting}

The fourth hypothesis is not supported empirically. Market activity is not significant to IFR. This means that market activity is not a determinant of IFR. Management discloses information on IFR not depending on market activity. Market activity is not a factor that will cause agency problems. The size of the information asymmetry that results in agency problems is not caused by market activity.

the results of this study have the same results as the research of indahsari (2019), which states that market activity has no effect on IFR. however, this result is different from the research conducted by hussain, rehman, and ishaq, 2018; budianto (2018), which states that market activity has a positive effect on IFR.

\section{Additional Test}

The additional test in this study aims to examine the determinants that most influence IFR in each country. The results of the normality, heteroscedasticity, and multicollinearity tests have passed. The $\mathrm{F}$ test for model eligibility does not pass. Therefore, we add the firm size variable as the control variable. The $\mathrm{F}$ statistical test shows a significance value of 0.000 in Indonesia, 0.000 in Malaysia, 0.022 in the Philippines, 0.021 in Singapore, 0.000 in Thailand; the results of the F-test after entering firm size are significant. This means that the research model can be used to test the hypothesis. The research equation for this additional test is as follows:

$I F R_{i}=\beta_{0}+\beta_{1}{ }^{*} P F_{i}+\beta_{2}{ }^{*} L K_{i}+\beta_{3}{ }^{*} L V_{i}+\beta_{4}{ }^{*} M B V_{i}+\beta_{5}{ }^{*} U P_{i}+\varepsilon_{i}$

The results of hypothesis testing for each country are shown in Table 5.

Table 5

Hypotheses Testing for Each Country

\begin{tabular}{|c|c|c|c|c|c|c|c|c|c|c|c|c|c|c|c|}
\hline & \multicolumn{3}{|c|}{ Indonesia } & \multicolumn{3}{|c|}{ Malaysia } & \multicolumn{3}{|c|}{ Philipina } & \multicolumn{3}{|c|}{ Singapore } & \multicolumn{3}{|c|}{ Thailand } \\
\hline & Koefisien & $\mathrm{t}$ & Sig & Koefisien & $t$ & Sig & Koefisien & t & Sig & Koefisien & t & Sig & Koefisien & $\mathrm{t}$ & Sig \\
\hline (Constant) & $-0,503$ & $-1,742$ & 0,086 & 0,106 & 0,595 & 0,553 & 0,017 & 0,070 & 0,944 & 0,325 & 1,880 & 0,066 & 0,013 & 0,093 & 0,926 \\
\hline $\mathrm{PF}$ & $-0,008$ & $-0,048$ & 0,962 & 0,132 & 1,628 & 0,107 & 0,154 & 0,784 & 0,438 & 0,121 & 1,759 & $0,085^{*}$ & 0,319 & 2,134 & $0,035^{* *}$ \\
\hline LK & 0,000 & 0,020 & 0,984 & $-0,007$ & $-1,155$ & 0,251 & $-0,001$ & $-0,153$ & 0,879 & 0,011 & 1,318 & 0,193 & $-0,018$ & $-2,460$ & $0,016^{* *}$ \\
\hline LV & $-0,071$ & $-2,934$ & $0,005^{* * *}$ & $-0,056$ & $-2,028$ & $0,046^{* *}$ & $-0,005$ & $-0,314$ & 0,755 & $-0,02$ & $-0,137$ & 0,892 & 0,039 & 2,016 & $0,047^{* *}$ \\
\hline MBV & 0,006 & 0,609 & 0,544 & 0,001 & 0,121 & 0,904 & 0,007 & 0,558 & 0,580 & $-0,010$ & $-1,397$ & 0,168 & 0,003 & 0,462 & 0,645 \\
\hline UP & 0,042 & 4,188 & $0,000^{* * *}$ & 0,029 & 3,190 & $0,001^{* * *}$ & 0,025 & 2,405 & $0,021^{* *}$ & 0,018 & 2,094 & $0,041^{* *}$ & 0,032 & 5,680 & $0,000^{* * *}$ \\
\hline
\end{tabular}

*** significant on $\mathrm{p}$-value $1 \%,{ }^{* *}$ significant on $\mathrm{p}$-value $5 \%$, * significant on $\mathrm{p}$-value $10 \%$

Source: processed data

The profitability $(\mathrm{PF})$ of the test for each country shows significant results with a positive coefficient value in Singapore of 0.121 and Thailand of 0.319. Meanwhile, Indonesia, Malaysia and the Philippines showed insignificant results. These results indicate that profitability has a positive and significant effect on IFR in Singapore and Thailand. From the results of this test, it can be concluded that profitability is the determinant of IFR in by Singapore and Thailand.

The liquidity (LK) of the test for each country showed significant results with a negative coefficient value in Thailand of -0.039. Meanwhile, Indonesia, Malaysia, Singapore and the Philippines showed insignificant results. From these results it can be 
concluded that liquidity has a significant negative effect in all countries contributed by the results obtained from Thailand which has a negative coefficient value.

Leverage (LV) is significant and negative for IFR in Indonesia and Malaysia. While in Thailand, leverage is significant and positive. Leverage is not significant to IFR in Singapore and the Philippines. The results of this additional test conclude that leverage is a determinant of IFR in Indonesia, Malaysia and Thailand. The main test shows that leverage is not significant to IFR. This is due to the insignificance of leverage against IFR in Singapore and the Philippines, which is very strong, thus reducing the level of significance in the countries of Indonesia, Malaysia and Thailand.

Market activity (MBV) is not significant to IFR in all ASEAN countries. This means that market activity is not a determinant of IFR on the ASEAN stock exchange.

Firm size (UP) in all countries shows significant results with a positive coefficient value. This shows that the firm size is the determinant of ifr of asean stock exchange. the role of firm size is strong, statistically on IFR. It means that large companies tend to disclose more on IFR that small companies.

\section{CONCLUSION AND SUGGESTIONS}

Based on the results of the analysis and discussion, the conclusions are. First, profitability has a positive impact on internet financial reporting (IFR) in manufacturing companies, the consumer goods sub-sector on the ASEAN Stock Exchange for the 20182019 period. The results also show that profitability has a positive impact on Singapore and Thailand. Meanwhile, in Indonesia, Malaysia and the Philippines, profitability has no impact on IFR. Second, liquidity has a negative impact on internet financial reporting (IFR) in manufacturing companies, the consumer goods sub-sector on the ASEAN Stock Exchange for the period 2018-2019. The results also show that liquidity has a negative effect on Thailand. Meanwhile, in Indonesia, Malaysia, the Philippines and Singapore, liquidity has no effect on IFR. Third, leverage has no impact on internet financial reporting (IFR) in manufacturing companies, the consumer goods sub-sector on the ASEAN Stock Exchange for the 2018-2019 periods. The additional test's result also shows that leverage has a positive impact on IFR in Thailand, but leverage has a negative impact on IFR in Indonesia and Malaysia. Meanwhile, in Singapore and the Philippines, leverage has no effect on IFR. Forth, market Activity has no effect on internet financial reporting (IFR) in manufacturing companies, the consumer goods subsector on the ASEAN Stock Exchange for the 2018-2019 periods. The results also show that market activity has no effect on IFR in Indonesia, Malaysia, the Philippines, Singapore, and Thailand.

This study has practical suggestions, profitability and liquidity can be used as consideration for users of financial statements before making investment decisions. Academic advice, profitability is a determinant of IFR that can reduce agency problems in companies with high levels of profitability. Meanwhile, liquidity has a role in reducing agency problems in companies with low liquidity levels. And company size can be used as a control variable because the results are conclusive on all ASEAN stock exchanges.

\section{REFERENCES}

Andriyani, R., and Mudjiyanti, R. (2017). Penerapan IFR Di BEI. Kompartemen, 15(1), 67-81.

Ardiastuti, Y., Widarno, B., Harimurti, F. (2019). Analisis Faktor yang Mempengaruhi Pelaporan Keuangan Perusahaan Melalui Internet. Jurnal Program Studi Akuntansi Fakultas Ekonomi Universitas Slamet Riyadi Surakarta, 609-620.

Budianto. (2018). Pengaruh Ukuran Perusahaan, Profitabilitas, Reputasi Auditor Dan Market Activity Terhadap Internet Financial Reporting Pada Perusahaan Manufaktur Yang Terdaftar Di Bursa Efek Indonesia. Jurnal Universitas Teuku Umar, 13-27

Hussain, A., Rehman, A., and Ishaq, A. (2018). The Determinants of Internet Financial Reporting in Pakistan. City University Research Journal, 8(2), 287- 297

Idawati, P.D.P., Dewi, I.G.A. (2017). Pengaruh Profitabilitas dan Ukuran Perusahaan Terhadap Internet Financial Reporting Perusahaan Manufaktur di Bursa Efek 
Indonesia, 15(2), 86-100.

Ilmawati, Y., dan Indrasari, A. (2018). Analisis Faktor-Faktor Yang Mempengaruhi Pengungkapan Internet Financial Reporting Di Indonesia Dan Malaysia (Studi Empiris Pada Perusahaan Manufaktur Yang Terdaftar Di Bursa Efek Indonesia Dan Bursa Malaysia Tahun 2014-2016. Reviu Akuntansi Dan Bisnis Indonesia 2(2):186-196

Indahsari, P.D. (2019). Pengaruh Ukuran Perusahaan, Umur Listing, Market Activity, dan Corporate Ownership terhadap Internet Financial Reporting. Jurnal Akuntasni Sekolah Tinggi Ilmu Ekonomi Perbanas Surabaya, 1-16

Jensen, M.C., and W.H. (1976). Theory Of The Firm: Managerial Behavior, Agency Costs And Ownership Structure. Journal of Financial Economics, 3(4), 305-360

Kieso, D.E., Weygandt, J.J., and Warfield, T.D. (2018). Intermediate Accounting (edisi ke-3) New Jersey: John Wiley dan Sons Inc.

Pervan, I. (2006). Voluntary Financial Reporting on the Internet Analysis of the Practice of Stock-Market Listed Croatian and Slovene Joint Stock Companies. Financial Theory and Practice, 30(1), 1-27.

Reskino, and Sinaga, N.N. (2016). Kajian Empiris Internet Financial Reporting Dan Praktek Pengungkapan. Media Riset Akuntansi, Auditing Dan Informasi, 16(2), 86-107.

Subramanyam, K.R., Wild, J.J., dan Halsey, R.F. (2010). Analisi Laporan Keuangan (edisi 11). Salemba Empat.

Sukanto, E. (2011). Pengaruh Internet Financial Reporting Dan Tingkat Pengungkapan Informasi Website Terhadap Frekuensi Perdagangan Saham Perusahaan Di Bursa. Jurnal Fokus Ekonomi, 6(2), 80-98

Suwardjono. (2014). Teori Akuntansi Perekayasaan Pelaporan Keuangan (edisi ke-3). Yogyakarta: BPFE-Yogyakarta.

Yassin, M.M. (2017). The Determinants of Internet Financial Reporting in Jordan: Financial versus Corporate Governance. International Journal of Business Information Systems, 25(4), 526-556. 